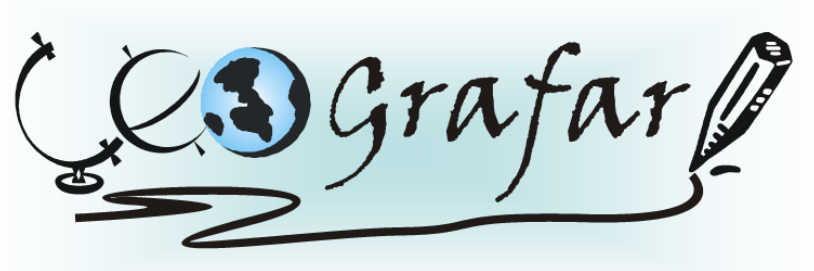

Revista Eletrônica do Programa de Pós-Graduação em Geografia - UFPR

\title{
O BRASIL NA GLOBALIZAÇÃO: CRÍTICA À PERSPECTIVA DE MILTON SANTOS
}

\section{BRAZIL IN GLOBALIZATION: CRITICAL THE PERSPECTIVE OF MILTON SANTOS}

\author{
(Recebido em 20.02.2014; Aceito em: 14.06.2014)
}

Fernando Antonio Salomão Loch

Mestre em Geografia

Curitiba, PR, Brasil

e-mail: fernandoloch@hotmail.com

Luis Lopes Diniz Filho

Prof. Dr. do Departamento de Geografia

Universidade Federal do Paraná

Curitiba, PR, Brasil

e-mail: diniz.ufpr@gmail.com

\begin{abstract}
RESUMO
O objetivo deste texto é fazer uma análise epistemológica das teses de Milton Santos acerca da globalização e confrontá-las com um estudo de caso sobre o Brasil do fim do século passado e início deste, com o fim de reavaliar criticamente a contribuição desse autor ao tema. Depois da introdução, a segunda seção fará o trabalho analítico, que consiste em identificar as fontes teóricas usadas por esse autor, além de analisar algumas de suas obras e o percurso argumentativo que ele trilhou para chegar às suas conclusões. As seções seguintes serão dedicadas ao estudo de caso, sendo que a terceira focará a mudança de paradigma da economia brasileira, quando o modelo de economia fechada é substituído por um de economia aberta, durante a década de 1990. Por sua vez, a quarta seção trata dos impactos dessa mudança sobre a população. Nos seus parágrafos se demonstrará o modo como a abertura comercial permitiu a queda da inflação, dando destaque ao mecanismo denominado "Âncora Verde", e a melhor acessibilidade alimentar da parcela mais pobre, fazendo com que, consequentemente, a população brasileira como um todo, melhorasse sua qualidade de vida. $O$ artigo finaliza com uma seção de considerações finais, onde se demonstra que a incoerência do pensamento de Milton Santos pode ser explicada pela sua opção ideológica.
\end{abstract}


Palavras-chave: Globalização; Abertura Econômica; Geografia Crítica.

\begin{abstract}
The aim of this paper is to make an epistemological analysis of Milton Santos theses about globalization and confront them with a case study on Brazil late last century and beginning of this, in order to critically reassess the contribution of this author's theme. After the introduction, the second section will do the analytical work, to identify the theoretical sources used by the author, in addition to analyzing some of his works and argumentative path he trod in reaching their conclusions. The following sections will be devoted to the case study: the third will focus on the paradigm shift of the Brazilian economy, when the closed economy model is replaced by an open economy, during the 1990s. In turn, the fourth section deals with the impact of this change on the population. Your paragraphs will demonstrate how trade liberalization allowed the fall in inflation, highlighting the so-called " Green Anchor ", and the best food accessibility poorer section mechanism, making hence the Brazilian population as a whole, improved their quality of life. The article concludes with a section of concluding remarks, demonstrating that the incoherence of thought Milton Santos can be explained by its ideological choice.
\end{abstract}

Keywords: Globalization; Economic Opening; Critical Geography.

\title{
1. INTRODUÇÃO
}

O objetivo deste texto é fazer uma análise epistemológica das teses de Milton Santos acerca da globalização e confrontá-las com um estudo de caso sobre o Brasil com o fim de reavaliar criticamente a contribuição desse autor ao tema. A primeira seção fará o trabalho analítico, que consiste em tentar identificar as fontes teóricas usadas por esse autor e o percurso argumentativo que ele trilhou para chegar às suas conclusões, enquanto as duas seções seguintes serão dedicadas ao estudo de caso. O artigo finaliza com uma seção de considerações finais.

Antes de dar início a essas tarefas, porém, cumpre ressaltar que o conceito de globalização, como todos os conceitos que tratam da relação entre sociedade e espaço, tais como região ou paisagem, é altamente polissêmico. Isso ocorre porque o conceito de globalização, em vez de designar um objeto empírico concreto, funciona como um instrumento intelectual que permite identificar, com base em critérios definidos pelo pesquisador, um conjunto de relações e processos cuja dimensão espacial é objeto de investigação científica. Daí que o termo globalização 
é empregado numa série de estudos que tratam de processos políticos, culturais, identitários, geográfico econômicos, e assim por diante. Neste trabalho, o conceito de globalização se refere aos processos de integração financeira, produtiva e comercial que, a partir do início da década de 1970, ampliaram a inserção dos sistemas econômicos nacionais na dinâmica da economia mundial.

Não se trata, pois, de pensar esses processos integrativos como tendo o condão de tornar as taxas de crescimento econômico dos vários Estados nacionais progressivamente indiferenciadas umas das outras, e nem como processos que tenderiam a produzir uma "fragmentação da economia nacional", entendida como a constituição de taxas de crescimento regionais dessincronizadas dentro de um mesmo território nacional. Há uma grande quantidade de estudos em geografia econômica que mostram o teor exagerado de pesquisas que, produzidas dos anos 1990 em diante, no Brasil e no exterior, viam a globalização com um processo que tornaria economicamente pouco relevantes as políticas nacionais e os fatores de produção localizados na determinação das trajetórias de desenvolvimento, ou que transformariam os territórios nacionais em mosaicos de sistemas produtivos fortemente conectados à economia mundial, mas com poucas articulações entre si (Cruz et. al., 2011; Diniz Filho, 2005; 2000). O objetivo, aqui, é apenas analisar os impactos sociais dos processos relacionados à globalização econômica no Brasil dos anos 1990 de modo a avaliar a consistência lógica e empírica das teorizações de Milton Santos sobre o que ele denominava "globalização perversa".

\section{MILTON SANTOS E A “PERVERSIDADE” DA GLOBALIZAÇÃO}

Dentro da vasta obra de Milton Santos, há pelo menos dois livros de destaque na discussão do assunto em pauta, motivo pelo qual foram selecionadas como base para esta seção. O livro Por uma outra globalização: do pensamento único à consciência universal é, assumidamente, um manifesto político (Santos, 2001), enquanto Técnica, espaço, tempo: globalização e meio técnico-científico informacional (Santos, 1994) consiste num conjunto de ensaios que articulam as reflexões teóricas que o autor elaborou sobre o tema ao longo de muitos anos, e que 
preparavam o caminho para a possível produção de uma obra mais ambiciosa e sistemática.

Nos dois livros, mas especialmente no primeiro, o autor faz um diagnóstico devastador das consequências sociais do modelo de globalização em curso, embora sem usar dados estatísticos para dar base a tal diagnóstico. E nenhum dos dois livros esclarece como deveria ser a "outra globalização" preconizada pelo autor, embora seja cristalino que Santos foi um defensor do projeto socialista e um apoiador do socialismo realmente existente, ainda que substituísse a palavra "socialismo" por expressões alternativas em seus trabalhos acadêmicos (Diniz Filho, 2003). De fato, um dos raros momentos em que o autor defendeu o socialismo usando diretamente essa palavra, e o justificou com base em seus estudos acadêmicos, foi numa entrevista à imprensa: "A cidade é o único lugar em que se pode contemplar o mundo como a experiência de produzir o futuro. Mas se criou toda uma liturgia anticidade. A cidade, porém, acaba mostrando que não existe outro caminho senão o socialismo" (Santos, 2002, p. 71). Assim, as diferenças entre as duas obras ficam por conta de que Por uma outra globalização foi redigida, como já era mesmo de esperar, num tom mais ácido e um tanto mais veemente, ao passo que Técnica, espaço, tempo se destaca por tecer discussões mais acadêmicas (Santos, 1994).

A contundência das críticas do autor à forma da globalização em curso ligavase diretamente ao contexto econômico e político dos anos 1990. No intuito de escapar da trajetória de baixo crescimento com altas taxas de inflação, iniciada entre o final da década de 1970 e o começo da seguinte, diversos países em desenvolvimento passaram a executar reformas estruturais orientadas para a ampliação dos seus fluxos de comércio internacional. Isso significava reduzir as barreiras tarifárias e não tarifárias às importações e promover o aumento das exportações por meio de políticas voltadas para a elevação da eficiência dos sistemas produtivos, tais como os programas de privatização de empresas estatais e dos serviços de infraestrutura. Significava, também, executar políticas macroeconômicas menos tolerantes com déficits fiscais e com o aumento das taxas de inflação, de modo a garantir um ambiente propício para investidores internacionais dos setores produtivo e financeiro. Em função disso, o termo 
"globalização" começou a ser utilizado, nos anos 1990, principalmente por políticos e economistas defensores da necessidade dessas reformas liberalizantes ${ }^{1}$.

Tudo isso explica a razão de um socialista radical como Milton Santos - ainda que bastante eclético no campo epistemológico - haver se preocupado em tecer um manifesto político em favor de "uma outra globalização" contrária àquela que estava em curso sob a égide do "neoliberalismo". Todavia, é preocupante constatar que, quando examinadas de perto, as reflexões teóricas e metodológicas desse autor não tinham mais consistência lógica e empírica do que seus discursos politizados. $\mathrm{Na}$ verdade, tanto as elaborações teóricas quanto seu manifesto consistiam na repetição de críticas seculares e superficiais à economia de mercado (de teor moral ou ideológico) sob diferentes formatos, sendo que os mais utilizados pelo autor eram o determinismo geográfico e o fetichismo espacial.

Realmente, o economista Albert Hirschman (1986), numa interessante revisão bibliográfica sobre as avaliações ideológicas e científicas acerca dos impactos sociológicos do funcionamento do mercado, identificou quatro teses fundamentais que, desde o século XVIII, procuram prever esses impactos e suas consequências para o futuro. São elas a "tese do suave comércio", a "tese da autodestruição do capitalismo", a "tese dos entraves feudais" e a dos "trunfos feudais". Para os propósitos deste artigo, porém, basta tecer um breve comentário sobre as duas primeiras.

A "tese do suave comércio" constata que a economia de mercado incentiva os indivíduos a deixar de produzir para si mesmos e se dedicar a produzir para outros com o fim de ganhar dinheiro. Assim, uma série inumerável de decisões fundadas no interesse econômico individual aprofunda a divisão social do trabalho e constitui uma rede de cooperação que amplia a produção e a produtividade do trabalho, bem como a alocação eficiente de recursos, beneficiando a todos com o atendimento das mais diversas necessidades. Foi basicamente esse o cerne do pensamento econômico da escola fisiocrática, representada especialmente por François Quesnay, e também de vários autores da fase clássica da ciência econômica, notadamente Adam Smith.

1 Armen Mamigonian, seguindo uma visão de mundo maniqueísta - que também era essencial no modo de pensar de Milton Santos (Diniz Filho, 2013) -, chega a dizer categoricamente: "A ideia de globalização foi criada pelos economistas de direita das universidades norte-americanas, o que estimulou os cientistas políticos da mesma posição ideológica a fabricar 'teorias' que ao mesmo tempo fossem úteis aos seus patrões e também rendessem alguns dólares para suas pesquisas, especialmente após a queda da URSS" (Mamigonian, 2003). 
Por conseguinte, a economia de mercado oferece incentivos econômicos para que os indivíduos deixem de lado rivalidades nacionais, étnicas e de outros tipos ao fazerem comércio, e também para que sejam fidedignos ao estabelecer contratos, na medida em que tais comportamentos multiplicam as oportunidades de negócios e estabelecem a confiança mútua necessária para a reiteração das transações comerciais. Trata-se, pois, de um sistema econômico individualista, impessoal e contratualista que, pelo incentivo econômico, "suaviza" os costumes e forja os valores morais que o sustentam, especialmente a confiabilidade no cumprimento dos contratos. Autores como Montesquieu frisaram a capacidade do livre comércio de estimular a busca da paz e de formas cordatas de relacionamento entre os povos e entre indivíduos de uma mesma sociedade.

Do outro lado da arena, a "tese da autodestruição" do capitalismo e da economia de mercado inverte os termos da equação. Em sua formulação conservadora e romântica, que remonta ao século XVIII, estabelece que os valores morais necessários ao bom funcionamento dos mercados, como honestidade e fidedignidade, precedem o capitalismo e têm base, sobretudo, nas tradições religiosas, sendo que os incentivos do mercado para a satisfação de interesses particulares teriam o efeito de erodir tais valores com o tempo. Portanto, a crítica romântica ao capitalismo se funda em argumentos morais e contrapõe à cooperação economicamente interessada os valores tradicionais de organização da sociedade, como os laços familiares, o dever de obediência, o apego à linhagem, entre outros.

De forma muito pertinente, Hirschman (1986, p. 19) demonstra que esse tipo de crítica moral aos efeitos sociológicos do funcionamento do mercado era reproduzido, no XIX, também por pensadores socialistas, a começar por Marx e Engels. Em suas obras de juventude, como $A$ ideologia alemã e o Manifesto comunista, a crítica empreendida ao capitalismo reproduzia o pressuposto conservador de um século antes (e mesmo a reação dos conservadores novecentistas à revolução industrial) ao assegurar que o desenvolvimento desse modo de produção conduziria a uma progressiva reificação das relações sociais, de tal modo que os laços familiares, de amizade, e assim por diante, apareceriam como se fossem relações entre coisas, trocas de mercadorias. Posteriormente, Marx procurou ir além dessa refutação de tipo moral ao formular uma interpretação crítica da economia política com o fim de provar cientificamente que o capitalismo contém 
contradições econômicas que, cedo ou tarde, inviabilizariam sua reprodução. Mas a crítica econômica ao capitalismo, cujo resultado mais maduro foi $O$ capital, jamais substituiu suas críticas ao efeito reificador que o mercado exerceria sobre a sociabilidade, uma vez que as críticas científicas e filosóficas de Marx à "sociedade burguesa" formavam um conjunto orgânico e carregado de influências científicas e românticas ${ }^{2}$.

Feita essa breve digressão, cumpre dizer que, quando se leem os trabalhos de Milton Santos a respeito da globalização, fica claro que suas conclusões, ao contrário daquelas derivadas da teoria econômica de Marx, não resultam da aplicação de um método científico à pesquisa empírica, pois consistem apenas numa série de raciocínios de causa e efeito fundados em dois pressupostos essenciais, a saber: as refutações de fundo moral que românticos e socialistas lançavam contra a economia de mercado, já nos séculos XVIII e XIX; e o pressuposto, vagamente relacionado a ideologias nacionalistas e/ou teorias marxistas da dependência, de que a competição nos mercados estabelece um jogo econômico de soma zero, ou seja, uma rede de relações econômicas na qual alguns países e classes sociais necessariamente enriquecem às custas do empobrecimento de outros países e de outras classes. Uma passagem do livro Técnica, espaço, tempo sintetiza com perfeição o modo como esses pressupostos se combinam na obra de Santos:

\begin{abstract}
Mas a busca da competitividade, tal como apresentada por seus defensores governantes, homens de negócio, funcionários internacionais - parece bastar-se a si mesma, não necessita de qualquer justificativa ética, como, aliás, qualquer outra forma de violência. A competitividade é um outro nome para a guerra, desta vez uma guerra planetária, conduzida, na prática, pelas multinacionais, as chancelarias, a burocracia internacional, e com o apoio, às vezes ostensivo, de intelectuais de dentro e de fora das universidades.

Como podemos, mesmo assim, admirar-nos de que, aqui e ali, estourem guerras e corra o sangue, já que a Nova Ordem Mundial que se constrói é baseada numa competitividade sem limites morais? (Santos, 1994, p. 35).
\end{abstract}

É completamente falso dizer que a preocupação em elevar a competitividade - seja lá o que isso signifique - não possui fundamento ético. Conforme visto, a questão dos impactos sociológicos do funcionamento do mercado vem sendo

2 Do mesmo modo que Hirschman, o filósofo Roberto Romano (1997) destaca as influências do romantismo sobre Marx, particularmente nítida nos trabalhos de juventude desse autor, caso de A ideologia alemã. 
debatida desde meados do século XVIII, sendo que os impactos sobre os valores éticos e morais constituíam o ponto central desse debate. Não por acaso, Adam Smith, o fundador da ciência econômica, era um filósofo e um moralista. Nesse sentido, quando economistas e políticos atuais se propõem a encontrar caminhos para aumentar a competitividade das empresas, é com vistas a acelerar o crescimento econômico, aumentar a produtividade do trabalho e, por conseguinte, melhorar a qualidade de vida das pessoas. Quais devem ser as políticas públicas a adotar para melhor atingir esses resultados é uma decisão que varia muito conforme a visão de competitividade com o qual cada autor e instituição trabalha, mas o debate sobre a competitividade possui uma fundamentação ética dada pela concepção, notória e bastante antiga, de que o desenvolvimento da economia de mercado é um meio para promover a cooperação social, não um fim em si mesmo ${ }^{3}$.

Obviamente, poder-se-ia argumentar que, na passagem citada, Santos talvez estivesse apenas denunciando que os políticos, intelectuais e empresários envolvidos nas discussões sobre competitividade concretamente defendiam suas posições sem tecer qualquer consideração de ordem ética ou social. Todavia, aceitar tal ponderação implica dizer que Milton Santos ignorava ou falseava os termos do debate sobre a competitividade, uma vez que, nos anos 1990, os propositores de políticas de competitividade sistêmica afirmavam a importância do Estado na criação de vantagens competitivas e os benefícios socioeconômicos esperados com esse tipo de intervenção (Esser et al., 1994). Nos EUA e Europa, muitos economistas e políticos que propunham a necessidade dessas políticas justificavam-nas alegando a necessidade de evitar que a transferência maciça de plantas industriais para a China, onde os custos de produção são baixíssimos, viesse a gerar desemprego em larga escala e rebaixamento do nível de salário médio no mundo desenvolvido (Krugman, 1999, p. 73). Na América Latina, autores influenciados pela tradição de pensamento econômico histórico-estruturalista utilizavam o conceito de competitividade sistêmica para sustentar a tese de que a industrialização já atingida pelos países dessa região só poderia ser consolidada, e rumar para a constituição dos setores industriais mais dinâmicos da terceira

3 Vale notar que, na época, havia importantes polêmicas entre os economistas sobre os conceitos de competitividade e seus possíveis usos para o planejamento estatal (Porter, 1993; Krugman, 1999), mas Milton Santos passou ao largo de qualquer consideração sobre o tema e nem esclareceu se estava se referindo à concorrência entre empresas ou ao conceito de competitividade nacional ou às duas coisas simultaneamente. 
revolução industrial, se pudesse contar com um conjunto de políticas públicas voltadas para a construção de vantagens competitivas, tais como a qualificação da mão de obra e o desenvolvimento de centros de pesquisa tecnológica (UNO/ECLAC, 1996; Coutinho; Ferraz, 1994).

Dito isso, cabe notar que a comparação explícita que Milton Santos faz entre competitividade e guerra é um chavão bastante utilizado nos debates públicos, muito embora as visões de mundo e projetos que eles veiculam variem imensamente. No final dos anos 1990, com efeito, Paul Krugman (1999, p. 68) já havia notado que a analogia entre comércio internacional e conflito militar se transformara no "[...] pensamento convencional entre os formuladores de política, líderes empresariais e intelectuais influentes - ou seja, entre as pessoas importantes". E a revisão bibliográfica que ele efetuou para demonstrar isso prova que tal metáfora servia de argumento para políticos e intelectuais que nada tinham de anticapitalistas e que faziam propostas de políticas públicas diferentes uns dos outros, tais como Lester Thurow, Robert Reich e Jeffrey Garten - as ideias do primeiro, por sinal, foram bastante elogiadas pelo presidente norte-americano Bill Clinton, enquanto os outros dois ocuparam cargos influentes em seu governo.

Isso, por si só, já chama a atenção para a superficialidade da visão de Milton Santos sobre a competição internacional, que se baseava numa metáfora útil à defesa de propostas e de interesses econômicos e políticos que, nos países desenvolvidos, não tinham relação nenhuma com o projeto socialista que esse autor considerava ser o único caminho que a humanidade poderia trilhar. A rigor, qualquer um que defenda a necessidade de uma intervenção mais ativa do Estado neste ou naquele setor da economia, independentemente de ser um socialista, um socialdemocrata, um nacionalista de direita ou de esquerda, ou mesmo um industrial temeroso com a exposição de sua empresa à concorrência internacional, pode usar uma retórica baseada na comparação entre economia mundial e disputa militar como justificativa para o seu pleito.

Assim, para que o uso dessa metáfora banalizada significasse algo mais do que retórica esquerdista na obra de Milton Santos, seria necessário que o autor construísse uma teoria sobre o funcionamento da economia internacional capaz de provar que a resultante das transações econômicas que se dão nessa escala é, necessariamente, um jogo de soma zero. Contudo, nem Por uma outra globalização, 
nem o livro Técnica, espaço, tempo apresentam qualquer construção teórica que pudesse cumprir essa exigência lógica, seja por meio de um esforço para elaborar uma teoria original sobre o tema ou, mais modestamente, pelo resgate de alguma das várias teorias das trocas desiguais formuladas nas décadas de 1960 e 1970.

Com efeito, quando Edward Soja (1993) se propôs a demonstrar o poder explicativo da geografia pela afirmação do poder "ativo" do espaço, procedeu a uma certa reinterpretação das teorias de Ernst Mandel no intuito de provar que existem "lugares que exploram lugares" e que o sistema capitalista não pode sustentar as taxas de lucro sem perpetuar essa forma de exploração. Apesar desse esforço ter fracassado, em virtude da incoerência entre as teorias das trocas desiguais e a teoria marxista do valor, além de outros problemas teóricos e metodológicos envolvidos nessa empreitada (Diniz Filho, 1999), não há dúvida de que Soja ao menos estava consciente de que não há como construir uma crítica teórica radical e consistente ao sistema econômico mundial sem passar por teorizações desse tipo. Por sua vez, Milton Santos descreve processos espaciais evidentes de maneira superficial, insere visões conspiratórias ligeiras no meio da exposição e fala de desigualdades socioeconômicas entre países e entre regiões como se a simples descrição já comprovasse sua assertiva de que a competitividade é como uma guerra e que produz literalmente conflitos armados com derramamento de sangue! Para demonstrar isso, vale a pena repassar alguns desses processos que o autor descreve no livro Técnica, espaço, tempo.

Santos afirma que a "aceleração contemporânea impôs novos ritmos ao deslocamento dos corpos e ao transporte de ideias, mas também, acrescentou novos itens à história". Os fatos e dados demográficos citados na sequência para ilustrar essa ideia óbvia são notórios e superficiais. Depois, o autor associa esse processo à noção de efemeridade e dispara: "esse efêmero não é uma criação exclusiva da velocidade, mas de outra vertigem, trazida com o império da imagem e a forma como, através da engenharia das comunicações, ao serviço da mídia, ela é engendrada, um arranjo deliberadamente destinado a impedir que se imponham a ideia de duração e a lógica da sucessão" (Santos, 1994, p. 30). Assim como em muitas outras passagens dessa e de outras obras do autor, além de suas entrevistas à imprensa, o que se tem aí é uma teoria conspiratória segundo a qual as pessoas são impedidas de enxergar a realidade social em sua verdadeira natureza por um 
arranjo proposital de agentes genericamente denominados "atores hegemônicos da economia, da cultura, da política" (Santos, 1994, p. 42). Até mesmo as teorias das quais Santos discordava eram sumariamente descartadas com esse procedimento. Na página 24 do livro em questão, a tese do aquecimento global antropogênico é qualificada como o produto de uma conspiração desse tipo.

Retomando, vê-se o autor sustentar que "a dimensão mundial é o mercado" e, logo depois, apresentar o que seria sua antítese: "a grande revolta se dá através do espaço, do lugar, ali onde a tribo descobre que não é isolada, nem pode estar só. Esse lugar tanto se pode chamar Ngoro Karabad como Los Angeles. O mundo da globalização doentia é contrariado no lugar" (Santos, 1994, p. 36). Assim, o mercado é caracterizado como uma força de efeitos sociais negativos sem nenhuma justificativa, enquanto os conflitos urbanos de qualquer natureza e em qualquer lugar do mundo são automaticamente classificados como formas de resistência à suposta perversidade da globalização.

Duas páginas depois, Santos elabora uma discussão de teor filosófico sobre a "quinta dimensão do espaço", que seria o cotidiano. À primeira vista, esse seria o momento em que ficaria explicada a contraposição entre lugar e globalização, mas não é o que acontece. A exposição começa dizendo o óbvio: "o espaço ganhou uma nova dimensão: a espessura, a profundidade do acontecer, graças ao número e diversidade enormes dos objetos, isto é, dos fixos, de que, hoje, é formado e ao número exponencial de ações, isto é, de fluxos, que o atravessam" (Santos, 1994, p. 38). Na sequência, são feitas considerações breves sobre tempo, espaço, cotidiano e lugar que serviriam de base para a afirmação de que, caso o espaço seja pensado não só como materialidade, que seria "o domínio da necessidade", mas também como "teatro obrigatório da ação, isto é, o domínio da liberdade", ficaria clara a importância do espaço para o "destino da História" (Santos, 1994, p. 39).

Ora, o fato das lutas políticas acontecerem na superfície terrestre, assim como quase tudo mais que diz respeito ao homem, não significa que o espaço em si mesmo seja fonte da liberdade de ação política e, portanto, peça fundamental para explicar a história. O que se tem aí, em que pesem os autores citados por Santos, é apenas fetichismo espacial afirmado por meio de um discurso vago. Além disso, nota-se que tais considerações não trazem absolutamente nenhuma informação concreta ou mesmo um argumento que justifique a caracterização do mercado 
mundial e das grandes empresas globais como forças de efeitos sociais negativos. Não há, portanto, motivo algum para ver essa afirmação óbvia da liberdade de ação política (obviedade disfarçada por um discurso que confunde o teatro das ações humanas com os próprios atores), como argumento que demonstre a suposta contraposição entre globalização e lugar.

Mais adiante, o autor afirma que o processo de globalização leva à "mundialização do espaço geográfico" e lista dez características desse espaço, que seriam a tendência à conformação do meio técnico-científico informacional e mais nove processos de natureza econômica. O primeiro é a "transformação dos territórios nacionais em espaços nacionais da economia internacional". Isso sugere que há uma redução da autonomia dos processos econômicos que ocorrem no interior dos territórios nacionais, mas o autor não faz qualquer comentário que aponte as possíveis implicações disso para as políticas públicas ${ }^{4}$. Um silêncio curioso, pois, como Santos acusava políticos e intelectuais de venderem a ideia de que a globalização não deixava espaço para alternativas, esse seria o momento de aprofundar a discussão para mostrar que os Estados nacionais ainda dispõem de poder de ação suficiente para trilhar outros rumos e quais poderiam ser estes. Em seguida, o autor lista seis características que, ou são tão evidentes que não geram nenhuma discordância e nem debate, ou expressam uma visão negativa da globalização completamente gratuita. Exemplo de obviedade é a afirmação de que há uma "concentração da produção em unidades menores", conforme fica claramente visível no caso da ampliação da produtividade da terra na agricultura. Já o exemplo de crítica gratuita fica por conta da repetição sumária da ideia de que haveria uma "tensão crescente entre localidade e globalidade à proporção que avança o processo de globalização" (Santos, 1994, p. 50-51).

Pouco adiante, o autor procura explicar novamente as causas dessa tensão, mas agora trocando raciocínios de tipo filosófico por um raciocínio econômico. Inicia dizendo que os objetos técnicos exigem, para a otimização dos processos produtivos, uma série de normas jurídicas, financeiras e de outros tipos, as quais,

4 Ao final do livro, o autor comenta que o Estado é menos importante na globalização por causa do estágio de racionalidade já atingido pela sociedade e pelo território. No caso brasileiro, isso se daria principalmente no estado de São Paulo e adjacências (Paraná, Mato Grosso do Sul). "É a 'mão invisível', que se realiza através do espaço obediente, das grandes empresas e das grandes organizações internacionais" (Santos, 1994, p. 180). 
embora elaboradas "em diversos níveis geográficos e políticos", acabam sendo "induzidas por organismos supranacionais e pelo mercado" em virtude da competitividade. A imposição dessas "normais globais" constituem, assim, verticalidades que esbarram nas horizontalidades, sendo que estas últimas constituem "[...] o domínio do cotidiano territorialmente partilhado com tendência a criar suas próprias normas, fundadas na similitude ou na complementaridade das produções e no exercício de uma existência solidária" (Santos, 1994, p. 56).

Todavia, essa explicação não vem acompanhada da descrição de qualquer processo histórico que possa servir como exemplo das tensões entre verticalidades e horizontalidades e, muito menos, como comprovação dos efeitos sociais e econômicos negativos atribuídos, ao longo do livro inteiro, ao funcionamento do mercado mundial. Do mesmo modo, nenhuma evidência é apresentada para comprovar que a similitude e/ou complementaridade de atividades produtivas espacialmente próximas tenha qualquer relação com o "exercício de uma existência solidária". Ao invés de dar exemplos concretos ou construir indicadores para demonstrar as ditas tensões e a suposta tendência ao seu acirramento, o autor pressupõe apenas que a proximidade e o pequeno alcance espacial de certas atividades produtivas, em termos de destino da produção, geram solidariedade por si mesmas, o que não passa de determinismo geográfico.

Mais adiante, quando trata da urbanização brasileira no contexto da globalização, prosseguem as descrições de processos evidentes entremeadas com juízos negativos sobre o mercado e discursos que fetichizam o espaço, conforme os exemplos a seguir:

Quem, na cidade, tem mobilidade - e pode percorrê-la e esquadrinhá-la - acaba por ver pouco da Cidade e do Mundo. Sua comunhão com as imagens, frequentemente prefabricadas, é a sua perdição. Seu conforto, que não desejam perder, vem exatamente do convívio com essas imagens. Os homens 'lentos', por seu turno, para quem essas imagens são miragens, não podem, por muito tempo, estar em fase com esse imaginário perverso e acabam descobrindo as fabulações. [...] Para os migrantes e para os pobres de modo geral, o espaço 'inorgânico' é um aliado da ação, a começar pela ação de pensar, enquanto a classe média e os ricos são envolvidos pelas próprias teias que, para seu conforto, ajudaram a tecer: as teias de uma racionalidade invasora de todos os arcanos da vida, essas regulamentações, esses caminhos marcados que empobreceram e eliminam a orientação ao futuro. Por isso, os 'espaço luminosos' da metrópole, espaços da racionalidade, é que são, de fato, os espaços opacos (Santos, 1994, p. 84-85). 
Essas passagens formam uma espécie de versão espacializada da ideia de reflexividade do trabalho que está na base do materialismo de Karl Marx. Afinal, enquanto este último afirmava que a inserção dos operários nos sistemas de produção tayloristas Ihes permitiria compreender a contradição fundamental do capitalismo, que seria a apropriação privada de uma riqueza cuja produção é crescentemente socializada, Milton Santos supõe que as vivências dos indivíduos nas cidades têm efeitos cognitivos de ocultação ou de desvendamento da realidade social a depender dos determinantes que estiverem por trás da produção dos objetos que compõem cada tipo de espaço. Contudo, é preciso notar que Marx elaborou uma crítica teórica ao capitalismo na tentativa de demonstrar que haveria contradições objetivas nesse sistema das quais os operários viriam a se dar conta cada vez mais, ao passo que, em Milton Santos, a natureza contraditória e perversa do capitalismo é um fato dado e os pobres acabam por tomar consciência disso simplesmente porque não usufruem do mesmo conforto oferecido à população de renda mais alta.

Ora, justamente por supor que a natureza contraditória do capitalismo é um dado óbvio, o autor nem se esforça para demonstrá-la mediante uma pesquisa aprofundada sobre o espaço. E o mesmo se dá quando Santos trata especificamente da inserção do Brasil na globalização, já que raciocina seguindo uma visão nacionalista extremamente simplificadora. Ao falar do período histórico atual, com efeito, ele afirma que é preciso levar em conta quatro "fatos" para compreender o Brasil, dentre os quais se destaca a vigência de um "modelo econômico" que:

[...] privilegia o que se poderia chamar de distorção da produção, uma produção orientada para fora, external oriented, uma distorção igualmente do consumo com maior atenção ao chamado consumo conspícuo, que serve a menos de um terço da população, em lugar do consumo das coisas essenciais, de que o grosso da população é carente. Há uma relação íntima de causa e efeito entre a distorção da produção e a distorção do consumo, o que está ligado às múltiplas formas de 'abertura' da economia nacional e tem um efeito sobre as outras dimensões da economia que são também geográficas, como a circulação e a distribuição (Santos, 1994, p. 142).

A suposição de que um crescimento econômico com uma participação um tanto maior do setor externo como fonte de dinamismo produz "distorções" como essas e implica necessariamente dar "maior atenção" - seja lá o que isso quer dizer - à produção de bens de consumo conspícuo é completamente gratuita. Afinal, o 
autor não apresenta a lógica econômica que sustentaria essa relação de causa e efeito. Supor que tal conclusão proveio do estudo sobre o espaço seria totalmente falso, já que as descrições feitas pelo autor de processos como urbanização, metropolização, aumento da especialização e complementaridade regionais, intensificação dos fluxos, etc., são ligeiras e superficiais, conforme a síntese já apresentada.

Nesse sentido, não resta alternativa a não ser constatar que, para Milton Santos, as "distorções" geradas por um modelo econômico com maior participação das exportações no crescimento era um "fato" simplesmente porque seu pensamento era pautado por dogmas ideológicos nacionalistas e pelas críticas de fundo moral à economia de mercado e/ou porque ele concordava plenamente com as análises de economistas, geógrafos e de outros intelectuais de esquerda que, ao longo dos anos 1990, criticaram exacerbadamente o modelo de integração competitiva que então se procurava implantar no Brasil. Sendo assim, uma crítica mais completa às teorias desse autor sobre a globalização demanda lançar luz sobre questões das quais ele não trata diretamente, que são as transformações econômicas ocorridas no Brasil das últimas décadas do século passado e seus impactos regionais e sociais.

\section{BRASIL: MUDANÇA DE PARADIGMA E SUAS REPERCUSSÔES ECONÔMICAS E REGIONAIS}

No Brasil, segundo Goldenstein (1998), o modelo econômico baseado na substituição de importações só conseguiu obter um relativo sucesso, em acelerar o crescimento econômico, em virtude do financiamento externo. Assim, era graças ao endividamento externo que o país conseguia complementar a poupança nacional e financiar a economia, evitando crises decorrentes da balança de pagamentos e da inflação. Esse sistema, entretanto, começou a entrar em colapso após as crises econômicas internacionais, decorrentes dos choques do petróleo, nos anos 1973 e 1979

Juntamente com o aumento de mobilidade de capitais, as crises fizeram com que os recursos externos se tornassem escassos no país. Sem esses capitais, o Estado não conseguia financiar seus gastos. A inflação, antes uma aliada do gasto 
público, dispara. A década de 1980 ficaria marcada por esse cenário de estagnação e pode ser dividida em três fases distintas. A primeira, entre 1980 e 1983, é marcada pela recessão econômica causada pela mesma crise que pôs fim ao modelo econômico anterior. Depois, entre 1984 e 1986, houve uma fase de recuperação, graças ao bom desempenho do setor exportador e crescimento do mercado interno. Entre 1987 e 1989, ocorreu a última fase, marcada pelo fracasso do Plano Cruzado e também pelos cortes de gastos e investimentos públicos, na tentativa de conter a galopante inflação. Lídia Goldenstein (1998) explica porque os planos econômicos fracassavam: a carência de capital estrangeiro era tão extrema que inviabilizava qualquer tipo de modelo econômico que possuísse a ambição de retomar o crescimento autonomamente:

\begin{abstract}
Assim, a dependência de recursos externos que, embora sempre tenha existido, não era tão explícita e profunda, se agrava sobremaneira, a ponto de tornar inviável qualquer alternativa de reconstrução de um modelo de crescimento que não passasse pelo retorno do fluxo internacional de capitais para o país. Os diferentes planos econômicos que se sucederam no anos 80 (Cruzado, Bresser, Verão e Collor) são a prova disso (Goldenstein, 1998, p. 132).
\end{abstract}

Para a autora, a abertura econômica seria uma pré-condição para a estabilização porque, sem ela, o capital estrangeiro não conseguiria articular a economia. Com o mercado interno protegido, as empresas não sentiam a necessidade de efetuar investimentos, inovar, diminuir custos e aumentar a produtividade. A elas, o mercado estava reservado, de modo que qualquer custo adicional poderia ser repassado ao preço final, garantindo sua margem de lucro e prejudicando, principalmente, os segmentos mais pobres da população.

Ao provocar tal mudança paradigmática, a abertura da economia, por sua vez, viabiliza a estabilização. Com a economia fechada, sem concorrência, era impossível romper com as praticas das empresas de jogarem quaisquer custos para preços. Não havia a necessidade de as empresas se esforçarem por diminuir custos, buscar aumentos de produtividade, investir em geral. O mercado lhes era dado, garantindo juntamente com margens de lucro especialmente elevadas, se comparadas com outros países (Goldenstein, 1998, p. 133).

Desse modo, para a autora, a mudança de paradigma econômico era inevitável. "O esgotamento do modelo nacional desenvolvimentista e a fartura da sociedade após 15 anos de inflação e estagnação desarticularam o arranjo até então existente" (Goldenstein, 1998, p. 135 - itálico no original). A continuação do modelo com 
economia fechada manteria o país sem capacidade de investir e, consequentemente, estagnado.

O começo da mudança do paradigma econômico se deu, enfim, no início da década de 1990, pois nesse período foram aplicadas políticas que visavam diminuir a influência do Estado na economia e a "integração competitiva" do país ao cenário econômico internacional (Diniz Filho, 2000). Essas diretrizes tiveram um tímido início no governo de Fernando Collor, entre 1990-1992, pois sua política econômica combinava liberação fiscal e financeira com medidas radicais para estabilização da inflação.

A inserção econômica do país na economia internacional se consolidou, efetivamente, no plano de estabilização denominado Plano Real. Esse, depois de nascer no governo de Itamar Franco (1992-1993), atingiu sua maturidade no governo de Fernando Henrique Cardoso (1994-2001). A sua pauta continha a desindexação da economia, privatizações, equilíbrio fiscal, abertura econômica, contingenciamento e políticas monetárias restritivas (Fiúza, 2006).

Segundo a proposta de governo de Fernando Henrique Cardoso (1994), com a manutenção do câmbio artificialmente valorizado e a redução de tarifas de importação, além da facilitação de serviços internacionais, haveria um aumento das importações e a instalação de diversas empresas estrangeiras no país. Com isso, o governo esperava estabilizar as taxas de inflação, pois o aumento da oferta pressionaria os preços para baixo e, ao mesmo tempo, modernizaria e diversificaria os produtos e serviços. As privatizações, por sua vez, tinham como justificativa a afirmação de que a iniciativa privada teria meios próprios de investimento, o que deixaria o governo mais livre para investir em áreas primordiais, além de tornar as empresas mais competitivas e ajudar no processo de enxugamento da máquina pública.

Pode-se perceber, pela descrição do próprio governo, a importância da integração econômica com o resto do mundo para o funcionamento do plano. Sem a inserção do país na globalização econômica, o plano não teria sido viável:

Sua espinha dorsal foi o prognóstico de que o desequilíbrio do setor externo ocasionado pela valorização do câmbio, além de financiável pela entrada de capital externo, constituiria um fenômeno transitório, a ser corrigido pela efetivação de reformas estruturais voltadas para a redução do "custo Brasil" e, portanto, para o aumento da competitividade internacional das empresas instaladas no país. Daí a importância atribuída à abertura comercial, à desoneração fiscal das 
exportações e do investimento produtivo, à desregulamentação da economia e das relações de trabalho, à privatização das empresas estatais e às políticas de concessão do direito de operação das redes de infraestrutura à iniciativa privada (Diniz Filho, 2000, p. 110).

Nesse contexto, verifica-se a grande importância das importações como fonte de captação de capital externo e, consequentemente, dinamismo econômico. Desse modo, a redução de tarifas de importação se tornou um mecanismo fundamental para o funcionamento do plano.

Para garantir as importações e, consequentemente, toda a manutenção do novo sistema econômico, é necessária a existência de reservas de uma moeda forte e estável. Além de garantir o comércio exterior, essas reservas teriam a função de proteger a moeda local contra ataques especulativos. Segundo Goldenstein (1998), o capital estrangeiro se apresenta sob duas formas: especulativo e produtivo. Os capitais especulativos são facilmente atraídos por altas taxas de juros, entretanto podem retornar ao país de origem ao menor sinal de fragilidade da economia local. Já os capitais produtivos, apesar de não serem tão facilmente atraídos, são menos sensíveis ao cenário externo.

Sem dúvida o Plano Real dependeu, e ainda depende em certa medida, de capital externo especulativo mas, ao mesmo tempo, criou as condições para a vinda de investimentos diretos que, ao contribuírem para a reestruturação produtiva, permitem o retorno de um crescimento sustentado (Goldenstein, 1998, p. 135).

A autora afirma ainda que, apesar do Plano Real ter sido alimentado por uma grande quantidade de capital especulativo, este permitiu que fosse criado um ambiente propício ao investimento externo, o capital produtivo.

Assim, infere-se que o Brasil se inseriu na globalização econômica no início dos anos 1990, quando o seu paradigma econômico foi transformado. De um modelo essencialmente voltado ao mercado interno, com indústrias protegidas, para uma economia integrada, mais "aberta", em que o comércio internacional possui um papel fundamental.

À época, as reformas encetadas no intuito de instaurar esse novo modelo foram veementemente criticadas pelos intelectuais que afirmavam a necessidade e importância de políticas mais ativas do Estado no campo econômico, algo bastante visível, por exemplo, na economia regional. Os mais conhecidos especialistas da área, tais como Wilson Cano, Clélio Campolina Diniz, Leonardo Guimarães Neto, 
Tânia Bacelar Araújo e Paulo Roberto Haddad, entre muitos outros, vaticinaram que a abertura da economia, as privatizações e a mudança do papel do Estado no desenvolvimento teriam o efeito de estancar ou até reverter o processo de desconcentração econômica espacial que havia ocorrido de 1970 até 1985, quando a crise do nacional-desenvolvimentismo colocou a continuidade desse processo em xeque. Todavia, os indicadores de participação das Unidades da Federação no PIB brasileiro, no valor da transformação industrial - VTI e no pessoal ocupado na indústria atestam que essas previsões estavam completamente erradas, pois a desconcentração econômica e industrial não só continuou em curso como ainda foi favorecida por tais reformas. Só para dar uma ideia disso, mencione-se que, de acordo com a Pesquisa Industrial Anual-Empresa (PIA-Empresa, 2000), do IBGE, a participação do estado de São Paulo no VTI nacional decresceu de 48,0\% para $45,3 \%$ nos anos $1985-2000$, enquanto sua participação no pessoal ocupado foi reduzida de $46,9 \%$ para $38,6 \%$ nesse mesmo período, contrariando as previsões que os economistas citados repetiram ao longo de toda a década de $1990^{5}$.

Milton Santos não trata desse assunto em seu livro Técnica, espaço, tempo, o que é, à primeira vista, bastante inusitado. Afinal, o que se tem aí é uma questão de inegável relevância para compreender as transformações espaciais engendradas no contexto da globalização, e numa perspectiva que articula diferentes escalas de análise, como diria Claudio Egler (1993). Como um assunto dessa importância pôde ficar de fora das reflexões de um geógrafo sobre espaço e globalização? Por que Santos comentou o aumento da especialização e da complementaridade entre as regiões mas calou-se sobre a desconcentração? A resposta mais provável é que o silêncio do autor foi uma precaução que ele tomou para não incorrer no mesmo erro de previsão dos economistas regionais da época sem ser, ao mesmo tempo, forçado a reconhecer que, ao menos no que diz respeito à desconcentração industrial e econômica, o modelo de integração competitiva favoreceu uma redução das desigualdades, e não o contrário.

Justamente por ter evitado falar desse assunto é que Milton Santos preferiu assentar suas críticas ao modelo de integração competitiva sobre o argumento nem um pouco aprofundado, como visto no final da seção anterior - de que a

5 Sobre os argumentos usados por esses autores à época e as razões de suas falhas de previsão, ver: Diniz Filho, 2005; 2000. 
orientação exportadora ocasionaria uma "distorção da produção" e do consumo, dando-se "maior atenção" às demandas de consumo conspícuo de uma minoria da população. É preciso averiguar essa questão mais de perto, portanto.

\section{IMPACTO SOBRE A POPULAÇÃO BRASILEIRA}

Conforme visto no item anterior, o ambiente econômico dos anos 1980 era dominado pela inflação descontrolada. Para se proteger, as empresas repassavam os custos decorrentes à população através do aumento de preços dos seus produtos, acelerando ainda mais o processo inflacionário As camadas mais abastadas, por sua vez, para manter seu poder de compra, recorriam à moeda estrangeira, principalmente ao dólar, e às aplicações financeiras, como o overnight. Luna e Klein (2009) explicam os métodos utilizados para driblar a inflação:

A inflação causava a deterioração de todos os salários, mas era mais perversa com os trabalhadores que não possuíam mecanismos efetivos para proteção. $A$ renda não proveniente de salário, especialmente a que estava ligada ao mercado financeiro, usava a indexação para proteger seus ganhos (Luna; Klein, 2009, p. 102).

Desse modo, quem mais sofria com a desvalorização constante era justamente a camada mais pobre da população que, sem muitas opções para se proteger, via o poder de compra de seu salário ser corroído diariamente.

Desse modo, a abertura econômica, ou seja, a inserção do país na globalização, deveria ser benéfica principalmente para os mais pobres, uma vez que um dos seus resultados prometidos seria a estabilização do seu poder de compra.

Em artigo publicado pelo Banco Mundial, Francisco Ferreira, Phillippe Leite e Martin Ravallion (2007) analisam a dinâmica da pobreza no Brasil entre 1985 e 2004 e chegam à conclusão de que ela diminuiu, ainda que sejam cautelosos quanto a sua magnitude. Defensores da ideia que o desenvolvimento econômico é benéfico para a população, afirmam que a diminuição da pobreza só não foi maior porque a elasticidade da relação entre crescimento econômico e redução da pobreza difere de acordo com os diferentes setores da economia beneficiados. Desse modo, haveria diferentes pattern of growth, ou seja, diferentes padrões de crescimento, sendo que o crescimento do setor de serviços possui maior capacidade de diminuir a pobreza que o crescimento da agricultura e da indústria. No caso do Brasil, o pequeno 
crescimento do terciário pós-1994 prejudicou a possibilidade de ser alcançada uma taxa de redução da pobreza ainda maior.

\begin{abstract}
We find that growth in the services sector was substantially more poverty-reducing than growth in either agriculture or industry... The lower growth rates in the services sector after 1994 (compared to period prior to 1994) had a (small) negative effect on the rate of poverty reduction, despite a small improvement in the elasticity of poverty with respect to agricultural growth (Ferreira; Leite; Ravallion, 2007, p. 23-24).
\end{abstract}

É importante salientar que os pesquisadores trabalham com a ideia de miséria absoluta, pois, pela sua conceituação, pobre seria aquele que ganha menos de um dólar por dia, utilizando o seu poder de compra para 1993.

Mesmo sem o padrão de crescimento ideal, os pesquisadores do Banco Mundial são taxativos quanto à importância da mudança da orientação política do Brasil nos anos de 1990, como se pode verificar no fragmento abaixo:

\begin{abstract}
But our results are also consistent with the view that the contemporaneous policy environment plays an important role in three ways: by affecting the sectoral composition of growth, by affecting the sensitivity of poverty to growth in each sector and, finally, by changing macroeconomic conditions and the redistributive role of the State. The sectoral pattern of growth changed markedly after the change in policy regime around 1994, when Brazil successfully stabilized prices and concluded a process of trade liberalization that favored sectors producing tradable goods. Aggregate growth became a more important factor against poverty, outweighing the poverty-increasing effect of the changing composition of growth (away from the service sector). This was helped by the fact that agricultural and industrial growth became relatively more poverty-reducing after the reforms (Ferreira; Leite; Ravallion, 2007, p. 4).
\end{abstract}

Desse modo, para os pesquisadores, o país efetivamente se inseriu na economia internacional em 1994 e essa mudança de paradigma macroeconômico possibilitou o comércio internacional de diversos produtos, inclusive alimentos, o que permitiu que a inflação ficasse sob relativo controle. Por sua vez, a estabilidade possibilitou, ainda no governo de Fernando Henrique Cardoso, a criação de programas sociais de distribuição de renda. Todos esses fatores levaram os setores agrícola e industrial a aumentar a sua capacidade de beneficiar as camadas mais pobres da população, fornecendo subsídios para explicar a diminuição da pobreza mesmo sem um grande crescimento econômico.

Nessa mesma linha de pensamento, Goldenstein (1998) já havia afirmado que, sob o ponto de vista da renda, a mudança de paradigma econômico teve um grande impacto distributivo. Essa renda advém do fim da faixa de lucro que os empresários 
obtinham unicamente devido ao mercado fechado, além dos ganhos na maior produtividade nacional e na menor quantidade de impostos. Para a autora, essa desconcentração faz com que um número cada vez maior de investimentos estrangeiros desembarcasse no país, mirando o crescente mercado consumidor. $O$ que as atrai não é apenas o aumento do poder de compra da população, mas também a grande oferta de crédito, o que pode causar um efeito multiplicador sobre o consumo.

Uma pesquisa do Instituto de Economia Aplicada - IPEA (2002) - realizou um levantamento dos investimentos produtivos no país, realizando uma comparação entre os períodos anteriores e posteriores à reforma econômica. Segundo a análise, com o esgotamento do modelo de substituição de importações, o Brasil dos anos 80 apresentou uma grande queda de investimentos em relação ao Produto Interno Bruto. A partir da abertura econômica, os investimentos passaram por um período de recuperação, conforme pode se verificar na Tabela 1, a seguir. Salienta-se que o investimento direto estrangeiro é mencionado pela abreviação IED e que a sigla FBKF refere-se à formação bruta de capital fixo.

TABELA 1 - INVESTIMENTO ESTRANGEIRO DIRETO NO BRASIL

\begin{tabular}{ccc}
\hline PERIOODO & IED EM RELAÇÃO AO PIB (\%) & IED EM RELAÇÃO AO FBKF (\%) \\
\hline 1976 até 1985 & 0,7 & 3,3 \\
1986 até 1994 & 0,2 & 1,1 \\
1995 & 0,8 & 3,8 \\
1996 & 1,4 & 7,0 \\
1997 & 2,3 & 11,7 \\
1998 & 3,6 & 18,4 \\
1999 & 5,9 & 31,3 \\
2000 & 5,7 & 30,6
\end{tabular}

FONTE: IPEA, 2002.

O Instituto construiu a tabela, principalmente, com base em dados do Banco Central e da FGV. Os dados permitem constatar que a referida retomada do investimento foi puxada em grande parte pelo capital estrangeiro. A formação de capital fixo refere-se à aquisição de edifícios, máquinas e equipamentos e se relaciona intimamente com o aumento da produtividade, o que, por sua vez, se 
relaciona com a diminuição do custo do produto, o que vai trazer benefícios à população, conforme será explicado posteriormente.

Para o IPEA (2002), apesar dos juros altos e da maior vulnerabilidade externa pós-abertura jogarem contra, a estabilização econômica e o consequente aumento de poder de compra da população foram os principais responsáveis por atrair o investidor estrangeiro. Por esse ponto de vista, a grande população brasileira acaba por gerar um grande mercado interno, o que seria uma vantagem para o país, em comparação aos outros, de menor população.

O modo como a agricultura e, consequentemente, os alimentos contribuíram para o controle da inflação é chamado pela leitura especializada de "âncora verde". Ela é apontada, junto com a "âncora cambial", como a responsável pelo reconhecido sucesso do Plano Real. Segundo artigo do IPEA (2003), ela é assim chamada porque além de evitar que os produtos da cesta básica se elevassem, ela também manteve estável o preço das matérias primas, não permitindo que a inflação adentrasse na cadeia produtiva, funcionando assim como uma verdadeira "âncora".

O mesmo artigo, que foi redigido em conjunto com a Comissão Econômica para a América Latina e o Caribe (CEPAL), fez uma revisão de diversos autores e enumerou diversos fatores que contribuíram para a queda dos preços dos produtos agrícolas. Os mais comuns seriam a valorização cambial, a elevação da produtividade da terra e a "normalização" do mercado pós-inflação, além da queda mundial pós-crise asiática. Com o câmbio controlado artificialmente pelo governo, a moeda nacional se valorizou frente ao dólar, o que tornou a exportação desinteressante, fazendo com que os produtores voltassem seus olhos ao mercado interno.

Desse modo, o mercado foi inundado pela oferta de produtos nacionais e internacionais, forçando a baixa do preço dos mesmos. O livre mercado também permitiu a importação de tecnologia, o que possibilitou a elevação da produtividade e da qualidade da terra. Considera, Souza e Bracale (2002), pesquisadores da Secretaria de Acompanhamento Econômico (SEAE), confirmam o aumento da produtividade e, para isso, se valeram de dados da Companhia Nacional de Abastecimento (CONAB) e do IBGE para calcular a taxa de crescimento médio anual da produção de diversos produtos. O resultado da pesquisa está apresentado na Tabela 2 a seguir: 
TABELA 2 - TAXA DE CRESCIMENTO MÉDIO ANUAL DE PRODUTIVIDADE DE PRODUTOS AGRÍCOLAS ENTRE 1994 E 2002.

\begin{tabular}{lc}
\hline PRODUTO & TAXA DE CRESCIMENTO \\
\hline Café & $-1,35 \%$ \\
Cana-de-açúcar & $1,50 \%$ \\
Arroz & $4,43 \%$ \\
Feijão & $3,65 \%$ \\
Milho & $2,94 \%$ \\
Soja & $2,70 \%$ \\
Trigo & $2,09 \%$ \\
Boi & $0,95 \%$ \\
Leite & $1,77 \%$ \\
MÉDIA GERAL & $1,89 \%$ \\
\hline
\end{tabular}

FONTE: CONSIDERA, SOUZA E BRACALE (2002)

Para chegar a esses resultados, os autores levaram em conta somente um dos fatores de produção: o fator terra. Já para os produtos pecuários, foi utilizado o abate e a produção de leite. Na tabela verifica-se que, apesar da produtividade do café ter diminuído, todos os outros itens apresentaram sensíveis melhoras. Esses ganhos na produtividade poderiam, inclusive, gerar um ganho na renda do produtor, mesmo com a queda no preço final ao consumidor, como será apresentado posteriormente.

Em um estudo sobre a indústria de biscoitos, Monteiro e Martins (2003), ao comentar sobre a desregulamentação do mercado de trigo no início da década de 90, demonstram uma consequência prática da abertura dos mercados e o fim dos monopólios estatais sobre a produtividade:

\begin{abstract}
Até aquele momento este grão só podia ser comercializado por intermédio do Banco do Brasil, o qual controlava desta forma, o preço do produto retardando o processo de melhoria de qualidade dos grãos. Tanto que, durante o monopólio, o Brasil produzia $75 \%$ do trigo consumido, poucos anos após a queda do monopólio o país produzia apenas $25 \%$ do total que consumia. Isto devido, principalmente, a várias décadas de um mercado fechado, controlado por uma empresa estatal, que priorizava o volume de produção nacional e deixava de lado a produtividade agrícola e a qualidade do produto (Monteiro; Martins, 2003, p. 01).
\end{abstract}

Considera, Souza e Bracale (2002) explicam ainda que a contribuição indireta do setor agrícola foi mais importante para o controle da inflação do que a própria contribuição direta. Em conformidade com o mecanismo "âncora verde", o grande 
comprador, ou seja, a indústria, teve papel fundamental nesse cenário. Ao comprar os produtos primários como matéria-prima, o setor secundário acaba por transmitir a queda de custo ao resto da cadeia produtiva, seja pela compra de insumos nacionais ou importados. Desse modo, apesar de algumas leituras fazerem referência a um "sacrifício da agricultura", é a indústria que merece o crédito final pela redução do preço da alimentação dos brasileiros.

Analisando o período entre 1989 e 1996, o IPEA (2002) confirmou o grande aumento de produtividade da indústria, confirmando a importância do setor. A variação positiva, mais de $50 \%$, teria sido uma das maiores do mundo e teria aproximado os níveis de produção brasileiros aos níveis dos países tidos como desenvolvidos:

A elevação média da produtividade do trabalho na indústria brasileira, entre 1989 e 1996, foi de $54 \%$. O desempenho foi muito superior ao que se registrou no resto do mundo - mesmo nos Estados Unidos, onde a produtividade cresceu fortemente - e permitiu uma redução na considerável distância entre a produtividade do trabalho brasileira e internacional (Ipea, 2002, p. 235).

Danielle Silva (2004) acredita que em economias fechadas a produção é menos eficiente porque a falta de concorrência não incentiva 0 investimento em tecnologia, assim como a utilização otimizada dos recursos. A autora, então, analisou a relação entre a diminuição das taxas aduaneiras e as variações na produtividade de 48 setores industriais do país. Apesar de apresentarem resultados heterogêneos, todos os setores foram afetados positivamente. Após esse resultado, a autora não só concordou com a premissa de que a mudança de modelo econômico foi produtivamente positiva, como afirmou que um dos determinantes da estagnação da indústria brasileira dos anos 80 foi o longo prazo de utilização de um modelo de substituição de importação.

De acordo com esses resultados é possível concluir que para a indústria de transformação a abertura e produtividade têm uma relação positiva e ao mesmo tempo mostra a ineficiência das políticas de restrição comercial como estratégia de desenvolvimento e de proteção à indústria. A estagnação da produtividade na década de 80 constitui uma evidência forte da conclusão acima. Dessa forma, pode-se questionar o modelo de substituição de importações como estratégia de crescimento de longo prazo. A baixa competitividade da indústria brasileira durante os anos de proteção acabou afetando o país (Silva, 2004, p. 34).

Ao afirmar que baixa competitividade afetou o país, Silva (2004) está se referindo ao fato de que, durante o período em que a economia não esteve plenamente 
integrada, ela deixou de obter os benefícios das economias de escala, mantendo diversos bens de consumo com preços passíveis de diminuição, afetando diretamente a população.

Antes mesmo de chegar às prateleiras dos supermercados, a abertura permitiu uma grande intensificação da competição varejista, fazendo com que os produtos, incluindo os alimentícios, passassem por melhorias em sua logística e distribuição comercial. A competição levou a fusões e aquisições por parte das grandes empresas, mas os concorrentes menores não chegaram a se extinguir, gerando um mercado ainda mais benéfico à população, conforme trecho abaixo do artigo de Considera, Souza e Bracale (2002):

No varejo, o aumento da pressão competitiva pode ser atribuído, em grande parte, ao crescimento do número de lojas de supermercados independentes, empresas com no máximo 4 lojas. A despeito da grande quantidade de fusões e aquisições, feita pelas cadeias de supermercados (mais de 5 lojas), a participação nas vendas dos supermercados independentes, no período de 1994 a 2000, subiu de $40 \%$ para $44 \%$, de acordo com Farina \& Nunes, utilizando-se dados primários da A.C. Nielsen. Já o market share das cadeias passou de 45,1\% em 1994 para 42,8\% em 2000. Tal fato demonstra que a concentração ocorreu primordialmente, entre as maiores empresas e não acabou com os concorrentes menores (Considera; Souza; Bracale, 2002, p. 11).

Isso subsidia a afirmação do trabalho de Ferreira, Leite e Ravallion (2007) visto anteriormente, o qual afirma que a mudança de paradigma econômico aumentou a capacidade da agricultura e da indústria de beneficiar os mais pobres. Seria uma das explicações para o processo investigado por esses autores, de diminuição da pobreza mesmo com um pífio crescimento econômico.

Passadas essas etapas, o alimento enfim chega ao consumidor varejista. Nesse sentido, quando Considera, Souza e Bracale (2002) se referem à "normalização do mercado", eles estão se referindo a esse momento de inflação controlada e sem remarcações diárias, em que os consumidores puderam enfim desfrutar da redução de preços. O seguinte trecho do artigo do IPEA (2003) exemplifica a baixa dos preços:

Entre agosto de 94 e agosto de 97, o preço real dos alimentos nas regiões metropolitanas brasileiras reduziu-se em cerca de $20 \%$, mantendo-se nesse patamar até hoje. Contudo, alguns produtos específicos como derivados de leite tiveram seus preços reduzidos entre 30 e $40 \%$ até 97 , sem recuperação posterior. O iogurte ficou famoso no cenário pós-estabilização. Um aumento de volume de demanda da ordem de $80 \%$ ocorria paralelamente a uma redução de preço de 
$40 \%$ real! O frango transformou-se em outro ícone do plano de estabilização (Ipea, 2003, p. 07).

Por sua vez, Lena Lavinas (1998) credita a melhora da acessibilidade alimentar muito mais ao aumento da renda do que à diminuição de preços. A melhor distribuição de renda, já demonstrada na seção anterior, permitiria aos mais pobres melhorar o seu consumo de alimentos. Ao mesmo tempo, ela não desconsidera a diminuição de preços, apenas a coloca em um lugar secundário. Desse modo, verifica-se que os alimentos ficaram mais acessíveis à população, tanto pela sua baixa de preços quanto pelo aumento de renda dos mais pobres.

O Ipea (2007) resume muito bem o modo como a abertura econômica aumentou o bem-estar social da população, em especial, a parcela mais pobre. Segundo o Instituto, a mudança de paradigma teve efeitos sobre a distribuição de renda e efeitos sobre o crescimento econômico. O principal efeito distributivo foi a já comentada queda da inflação. A estabilidade permitiu que o governo expandisse programas de distribuição de renda, assim como permitiu o aumento do salário mínimo e do bem-estar social, conforme a Figura 1 abaixo:

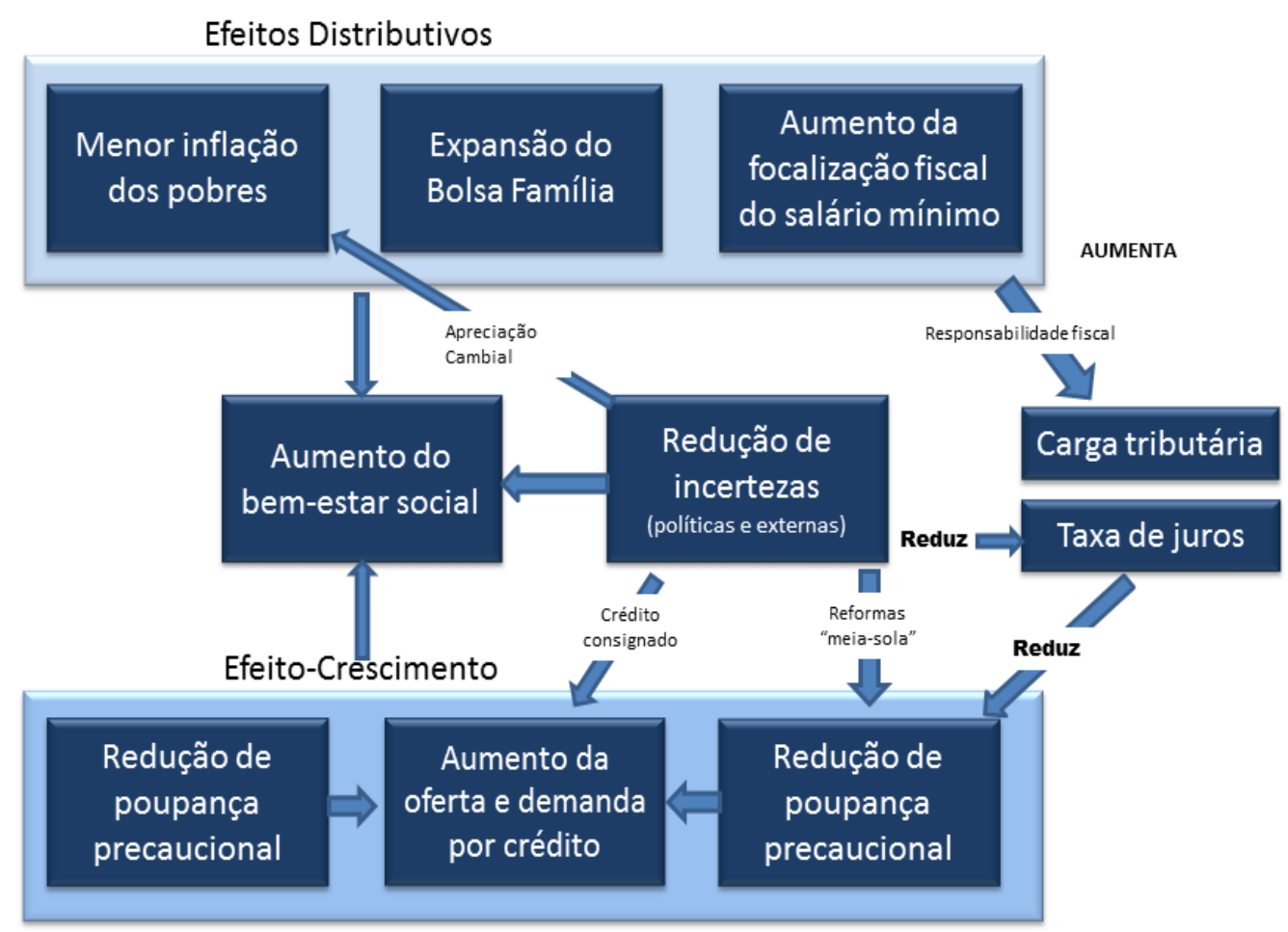

FIGURA 1 - EFEITOS DA MUDANÇA DE PARADIGMA ECONÔMICO FONTE: IPEA, 2007. 
$\mathrm{Na}$ mesma figura pode-se verificar que a abertura, em um ambiente de incertezas reduzidas, trouxe novamente o capital estrangeiro para o país, o que aumentou a oferta de crédito, fazendo com que, a longo prazo, as taxas apresentem uma tendência de queda, ainda que sejam altas em um momento inicial. A elevação da demanda por crédito e a maior disponibilidade deste, bem como a redução da poupança precaucional, levam ao aumento de investimento, causando efeitos positivos no crescimento. As reformas chamadas "meia-sola" compreenderiam as reformas trabalhistas dos anos 1990 e colaborariam no efeito crescimento.

Desse modo, infere-se que a mudança de paradigma econômico, que também pode ser entendida como um aprofundamento da inserção do país na globalização, aumentou o bem-estar da população, em especial, o dos mais pobres. A abertura permitiu que a produtividade nacional aumentasse, através da importação de produtos e insumos mais baratos. O efeito positivo foi repassado para toda economia, o que permitiu a estabilidade das taxas da inflação em baixos patamares e o aumento do poder de compra dos brasileiros. Esses fatores fazem entender os mecanismos que levaram o Brasil, apesar do baixo crescimento econômico, a reduzir a pobreza na última década do século $X X$.

As informações apresentadas atestam o equívoco completo de Milton Santos ao escrever que um modelo de desenvolvimento export oriented implica conceder "maior atenção" aos bens de consumo conspícuo, em detrimento das necessidades básicas da maioria da população, e que isso seria um "fato". Nesse sentido, o autor incorreu no mesmo erro de economistas como João Manuel Cardoso de Mello, Maria da Conceição Tavares, Luiz Gonzaga de Mello Belluzzo, entre muitos outros, segundo os quais as reformas dos anos 1990 levariam ao aumento da pobreza e/ou da desigualdade de renda. Muito pelo contrário, os dados da Pesquisa nacional por amostra de domicílio - PNAD provaram que, em 1995, logo após o lançamento do Plano Real, deu-se início a um longo processo de redução da desigualdade de renda (Hoffman, 2006), o qual perdura até hoje.

De fato, uma pesquisa sobre os impactos das mudanças nos preços relativos de bens e serviços no período que vai de 1995 a 2005 revelou que as privatizações, a política de juros altos e a valorização cambial tiveram o efeito de onerar mais as cestas de consumo das famílias de renda média e alta do que das famílias mais pobres, o que é um dos fatores explicativos da desconcentração de renda ocorrida 
nesses anos. As razões para isso são: a) taxas de juros elevadas oneram mais os gastos das pessoas de renda média e alta, que recorrem mais ao financiamento para a compra de bens; b) embora a privatização do sistema Telebras tenha, pela primeira vez na história brasileira, popularizado os serviços de telefonia, os aumentos de preços desses serviços se deram acima da média da inflação nos anos seguintes, o que teve maior impacto sobre os orçamentos das famílias de renda mais elevada, que gastam mais com telefonia; c) a valorização do câmbio, conforme visto, rebaixou os preços dos alimentos, o que beneficiou principalmente as famílias de menor renda, que dispendem um percentual maior de seus orçamentos familiares com a compra de itens de alimentação. Em uma palavra:

Se as explicações anteriores são reais, não deixa de ser curioso, no entanto, que haja uma certa inversão ideológica. As políticas defendidas por indivíduos mais de direita, no espectro político, tais como juros altos e privatizações, lesaram mais os mais ricos que os mais pobres. Já a taxa de câmbio real desvalorizada, defendida pelos mais de esquerda, essa, quando ocorreu, trouxe o efeito inverso (Osório; Soares, 2006, p. 205).

Mais uma evidência de que as conclusões de Milton Santos sobre os impactos da globalização, embora enunciadas como se resultassem da análise dos fatos, provinham de pressupostos ideológicos e/ou de convicções apriorísticas que ele partilhava com outros intelectuais de esquerda.

\section{CONSIDERAÇÕES FINAIS: EM LUGAR DE TEORIA E MÉTODO, IDEOLOGIA E RETÓRICA}

Neste ponto, é possível objetar que as críticas tecidas até o momento não levam em conta que Santos comandou a elaboração de uma pesquisa detalhada sobre a realidade social e espacial brasileira, com destaque para o período mais recente, ao publicar Brasil: território e sociedade no início do século XXI. Contudo, apesar do seu generoso volume, e da grande quantidade de informações estatísticas empregadas, a verdade é que as avaliações negativas efetuadas neste artigo se mantém quando se examina essa última obra.

Realmente, é com o objetivo de provar que o espaço não constitui apenas um "palco" onde os acontecimentos se dão, mas também um "ator" de grande importância para explicar o Brasil, que o livro de Milton Santos acaba lançando mão de um fetichismo espacial disfarçado por artifícios de retórica (Santos; Silveira, 2003, p. 265), conforme já concluíram outros estudos (Diniz Filho, 2013, p. 44; Vesentini, 
2001). E é justamente pela impossibilidade de realizar tal objetivo teórico sem apelar para um fetichismo espacial simplificador que as informações quantitativas citadas nesse livro se mostram incapazes de ir além de descrições superficiais da realidade.

\begin{abstract}
Existe nas 473 páginas dessa obra um amontoado de dados estatísticos, mapas e informações descritivas, que podem ser facilmente obtidos por qualquer pessoa em almanaques ou anuários especializados - sobre a rede bancária no Brasil, os aeroportos, as redes de transportes, as refinarias de petróleo e os dutos, os shopping centers etc. - e nenhuma tese ou ideia nova a respeito do significado disso tudo, apenas a constante repetição, em cada capítulo, de que "alguns espaços mandam" (o Sudeste, especialmente São Paulo) e outros "obedecem". Não existe nenhuma análise dos sujeitos, das classes ou grupos sociais, e nem mesmo qualquer referência às lutas e conflitos ou aos projetos que (re)constroem o espaço ou o território (Vesentini, 2001).
\end{abstract}

Uma boa demonstração dessa superficialidade é o momento em que os autores abordam a desconcentração industrial brasileira - tema que, conforme visto, foi ignorado em Técnica, espaço, tempo. No livro Brasil: território e sociedade no início do século XXI, Santos e Silveira (2003, p. 116) descreveram o processo de desconcentração industrial baseando-se em dados estatísticos de número de empresas, produção, emprego e localização das sedes das grandes empresas industriais no período que vai de 1970 a 1990, embora sem mencionar as fontes dos dados. Mas o curioso é que, além de não terem feito nenhuma discussão sobre as causas desse processo, escreveram a expressão "a 'descentralização' industrial" colocando a palavra "descentralização" entre aspas, o que dá a entender que se tratava de uma descentralização apenas aparente. Ainda assim, não tiveram o trabalho de esclarecer porque foram usadas as aspas se, conforme os dados que apresentaram, diminuiu a participação relativa do estado de São Paulo na indústria brasileira durante o período considerado.

Nesse sentido, a comparação entre Técnica, espaço, tempo e o livro publicado em parceria com Maria Laura Silveira permite explicar os silêncios de Milton Santos como estratégias de retórica a serviço de sua luta ideológica contra o capitalismo: ele procurava não explicitar a redução das disparidades regionais ocorrida no período anterior a 1990 (mesmo quando usava informações que provavam esse fato), deixava de apresentar uma explicação para tal processo, escapava de repetir a previsão equivocada de que as reformas efetuadas nessa década viriam a ter efeitos concentradores e, por fim, se eximia de admitir que tais reformas tiveram precisamente o efeito inverso! 
Já nos momentos em que Milton Santos fazia afirmações mais claras e categóricas sobre as consequências da globalização para o Brasil, o que se via era, além da já comentada ausência de uma teoria que explicasse a lógica econômica por traz da dita "perversidade" do mercado mundial, uma visão nacionalista e/ou de fetichismo espacial que pensava as transações comerciais entre países como se fossem uma competição entre empresas privadas do mesmo ramo de atividade. Isso fica bem demonstrado no momento em que o autor afirma, como visto, que um modelo econômico export oriented implica diversas "distorções" da produção e do consumo.

Paul Krugman explica essa questão didaticamente ao comentar um dos seis erros mais comuns que se cometem nos debates sobre economia internacional e que economistas formados não deveriam cometer:

\begin{abstract}
Um dos mais comuns e persistentes erros dos homens práticos é achar que os países, à semelhança das empresas do mesmo ramo, estão em competição mútua. Ricardo já sabia disso em 1817. Um curso de graduação em economia deveria inculcar nos estudantes a ideia de que o comércio internacional não diz respeito à competição, mas à troca mutuamente benéfica. $\mathrm{E}$ o que é mais básico, deveríamos poder ensinar aos alunos que as importações, e não as exportações, são o propósito do comércio internacional. Ou seja, o que um país ganha com o comércio internacional é a capacidade de importar coisas que deseja (Krugman, 1999, p. 118).
\end{abstract}

Milton Santos estava longe de ser um "homem prático", isto é, um formulador de políticas públicas, mas pensava igualmente o comércio entre países como se fosse uma disputa de mercado entre duas empresas que vendem produtos praticamente idênticos, como a Coca-Cola e a Pepsi, já que o mercado de uma efetivamente não pode crescer sem que o mercado da outra se reduza. Essa é uma dinâmica que, obviamente, pode trazer preocupações para os dirigentes e acionistas de cada empresa envolvida, mas que funciona de forma benéfica para os consumidores e nada tem a ver com um raciocínio baseado em territórios econômicos nacionais, visto que, nesse âmbito, o que acontece são trocas reciprocamente vantajosas de bens produzidos com o máximo de eficiência.

Exatamente por não ter percebido isso é que Milton Santos cometeu o equívoco de pensar que haveria algum tipo de incompatibilidade entre produzir para o mercado interno ou para exportar, quando o que existe, especialmente sob a égide da globalização, é uma complementaridade entre os mercados nacionais. Os anos 1990 atestam isso muito bem. Sendo um país de renda média, o Brasil 
recebeu investimentos em plantas da indústria automobilística especializadas na produção de carros populares, de tal modo que as exportações de automóveis produzidos aqui visam o mercado chinês e de outros países de renda média ou baixa. Outro ótimo exemplo é a indústria de aparelhos celulares, que se instalou no Brasil após a privatização do sistema Telebras para atender à imensa demanda reprimida por esse produto, mas que em poucos anos já havia começado a exportar (Goldenstein; Barros, 1997). Mencione-se, por fim, o exemplo da agricultura brasileira, visto que, como já notaram alguns geógrafos, "os setores exportadores são concomitantemente os que mais desenvolveram o consumo interno nas últimas décadas (laranja, frango, açúcar, frutas, entre outros)" (Broietti; Medeiros; Sampaio, 2005, p. 22). É o mesmo que se constata pelo exame dos dados da Pesquisa de Orçamentos Familiares sobre os padrões de consumo alimentar no Brasil (IBGE, 2004; 2010).

Caminhando para o encerramento, é bom destacar que, numa das entrevistas que encerram o livro Técnica, espaço, tempo, Milton Santos faz, ao tratar das contribuições e limites da geografia crítica, bem como do pouco interesse que os intelectuais brasileiros devotam às questões internacionais, a seguinte avaliação:

Então, uma boa parcela do que hoje aparece como geografia marxista é ideológica: trabalha com uma história que não existe mais, daí uma certa fixidez dos conceitos. [...] Há ainda um outro aspecto, que vem da questão crítica: quando a crítica não é acompanhada pela análise, ela permite a mobilização mas não a construção. A crítica deveria suceder a análise, mas o que acontece, na maioria dos casos, é que a necessidade de ser crítico opera como se o analítico fosse dispensável. Isto também é um fator de atraso. Aliás, é algo que atrasa também o trabalho dos partidos de esquerda, pois no Brasil estes partidos não são analíticos, são críticos (Santos, 1994, p. 172 - sem negrito no original)

É absolutamente correto dizer que a geografia marxista fazia (e ainda faz) pouca análise e muita crítica ideológica, valendo até acrescentar que essa fragilidade está presente também entre os geógrafos críticos não marxistas e se revela tanto na pesquisa acadêmica quanto em suas propostas de planejamento e na geografia escolar (Diniz Filho, 2013). Todavia, Milton Santos parece não ter percebido que seu diagnóstico se aplicava igualmente ao manifesto político que ele redigiu em prol de "uma outra globalização" e também às suas teses sobre a globalização realmente existente, fenômeno cuja suposta perversidade, atrelada à 
competição nos mercados, constituía um ponto de partida para os estudos dele sobre o espaço, quando deveria ser o ponto de chegada.

Mas a incoerência não surpreende, já que, conforme assinala Albert Hirschman (1986), as previsões catastrofistas dos defensores da tese da autodestruição do capitalismo, como aquelas de fundo moral, nunca se concretizaram. Além disso, esse autor já constatava, nos anos 1980, que o mercado produz simultaneamente efeitos de enfraquecimento e de fortalecimento da sociabilidade, ao passo que a sociologia econômica contemporânea vem demonstrando que os mercados "se organizam a partir da própria vida social", reiterando laços sociais e identitários por meio das transações econômicas (Abramovay, 2006). Nesse sentido, estudos sobre o espaço não poderiam mesmo ser o ponto de partida para confirmar as críticas morais de teor radical que Milton Santos lançava contra a competição e o mercado. Os impactos socioeconômicos e territoriais das reformas empreendidas no Brasil dos anos 1990 só reforçam tal conclusão, bem ao contrário do que afirmava esse autor.

\section{REFERÊNCIAS BIBLIOGRÁFICAS}

ABRAMOVAY, R. O mercado na sociedade e a sociedade no mercado. Valor Econômico, 27 nov. 2006. Disponível em: <http://www.eagora.org.br/conteudo.php?id=4641_0_3_0_C17> Acesso em: 31 mar. 2007.

BROIETTI, M. H.; MEDEIROS, M. C.; SAMPAIO, F. S. Dinâmica capitalista na agricultura brasileira: acumulação e relações de trabalho. Cadernos Geográficos, Florianópolis, n. 11, p. 1-78, maio 2005.

CARDOSO, F. H. Mãos à obra Brasil: proposta de governo. Brasília, 1994.

CONSIDERA C. M.; SOUZA E. L. L.; BRACALE G. Âncora Verde: o papel da agricultura no ajuste econômico. Brasília, 2002.

COUTINHO, L. G.; FERRAZ, J. C. (coord.). Estudo da competitividade da indústria brasileira. 2· ed. Campinas: Papirus; Editora da Universidade Estadual de Campinas, 1994.

DINIZ FILHO, L. L. A dinâmica regional recente no Brasil: desconcentração seletiva com internacionalização da economia internacional. São Paulo: Tese (Doutorado) USP/Programa de Pós-Graduação em Geografia Humana, 2000. 
DINIZ FILHO, L. L. A geografia crítica brasileira: reflexões sobre um debate recente. Geografia, Rio Claro, v. 28, n. 3, p. 307-321, set.-dez. 2003.

DINIZ FILHO, L. L. Os equívocos da noção de "regiões que exploram regiões": crítica ao conceito de "transferência geográfica de valor" de Edward Soja. Revista do Departamento de Geografia, n. 13, 1999.

DINIZ FILHO, L. L. Para onde irão as indústrias? In: ALBUQUERQUE, E. S. (org.). Que país é esse? : pensando o Brasil contemporâneo. 1. ed. São Paulo: Globo, 2005.

DINIZ FILHO, L. L. Por uma crítica da geografia crítica. Ponta Grossa (PR): Editora da UEPG, 2013.

EGLER, C. G. Crise e questão regional no Brasil. Tese (Doutorado), Unicamp/Programa de Pós-Graduação em Economia, 1993.

ESSER, K. et al. Competitividad sistémica: competitividad internacional de las empresas y políticas requeridas. Berlin, Instituto Aleman de Desarrollo, 1994 (Série "Estudios e Informes").

FERREIRA, F. H. G.; LEITE, P. G.; RAVALLION, M. Poverty Reduction without Economic Growth? Explaining Brazil's Poverty Dynamics, 1985-2004. Word Bank, 2007.

FIÚZA, G. 3.000 dias no bunker. Rio de Janeiro: Record, 2006.

GOLDENSTEIN, L.; BARROS, J. R. M. Avaliação do processo de reestruturação industrial brasileiro. Revista de Economia Política, v. 17, n. 2 (66), abr./jun.1997.

GOLDENSTEIN. L. Repensando a dependência após o Plano Real. Estudos Avançados. São Paulo: IEA/USP, vol. 12, n. 33, 1998.

HIRSCHMAN, A. Poder e fraqueza da sociedade de mercado: interpretações rivais, de Montesquieu a nossos dias. In: A economia como ciência moral e política. São Paulo: Brasiliense, 1986.

HOFFMAN, R. Queda da desigualdade da distribuição de renda no Brasil, de 1995 a 2005, e delimitação dos relativamente ricos em 2005. In: BARROS, R. P.; FOGUEL, M. N.; ULYSSEA, G. (org.). Desigualdade de renda no Brasil: uma análise da queda recente. Brasília: Ipea, v. 1, 2006.

INSTITUTO BRASILEIRO DE GEOGRAFIA E ESTATÍSTICA (IBGE). Pesquisa de orçamentos familiares 2002-2003: análise da disponibilidade domiciliar de alimentos e do estado nutricional no Brasil. Rio de Janeiro: IBGE, 2004.

INSTITUTO BRASILEIRO DE GEOGRAFIA E ESTATÍSTICA (IBGE). Pesquisa de orçamentos familiares 2008-2009: antropometria e estado nutricional de crianças, adolescentes e adultos no Brasil. Rio de Janeiro: IBGE, 2010. 
INSTITUTO DE ECONOMIA APLICADA (IPEA). A Evolução do Sistema Agroalimentar no Brasil e a Redução de Preços para o Consumidor: Os Efeitos da Atuação dos Grandes Compradores. Brasília: IPEA, 2003.

INSTITUTO DE ECONOMIA APLICADA (IPEA). Desigualdade de renda no Brasil: uma análise da queda recente. Brasília: IPEA, 2007.

INSTITUTO DE ECONOMIA APLICADA (IPEA). Investimentos e reformas no Brasil: Indústria e infra-estrutura nos anos 1990. Brasília: IPEA, 2002.

KRUGMAN, P. Internacionalismo pop. Rio de Janeiro: Campus; São Paulo: Publifolha, 1999.

LAVINAS, L. Acessibilidade Alimentar e Estabilização Econômica no Brasil dos anos 90. Rio de Janeiro: IPEA, 1998.

LUNA, F. V.; KLEIN, H. S. Desigualdades e Indicadores Sociais no Brasil. In: SCHWARTZMAN et al. O Sociólogo e as Políticas Públicas. Rio de Janeiro: Editora FGV, 2009.

MAMIGONIAN, A. Imperialismo, universidade e pensamento crítico. Princípios, n. 71,nov./dez./jan. 2003-2004. Disponível em:

<http://www.grabois.org.br/portal/cdm/revista.int.php?id_sessao=50\&id_publicacao= 180\&id_indice=1339> Acesso em: 04 mar. 2014.

MONTEIRO, A. R. G., MARTINS, M. F. Processo de desenvolvimento de produtos na indústria de biscoitos: Estudos de casos em fabricantes de médio porte. Gramado: 2003.

OSÓRIO, R. G.; SOARES, S. S. D. Desigualdade e bem-estar no Brasil na década da estabilidade. In: BARROS, R. P.; FOGUEL, M. N.; ULYSSEA, G. (org.). Desigualdade de renda no Brasil: uma análise da queda recente. Brasília: Ipea, v. $1,2006$.

PORTER, M. E. A vantagem competitiva das nações. Rio de Janeiro: Campus, 1993.

ROMANO, R. Conservadorismo Romântico. 2. ed. São Paulo: Ed. UNESP, 1997.

SANTOS, M. O país distorcido: o Brasil, a globalização e a cidadania. São Paulo: Publifolha, 2002.

SANTOS, M. Por uma outra globalização: do pensamento único à consciência universal. São Paulo: Record, 2001.

SANTOS, M. Técnica, espaço, tempo: globalização e meio técnico-científicoinformacional. São Paulo: Hucitec, 1994 (Geografia: Teoria e Realidade, 25).

SANTOS, M.; SILVEIRA, M. L. (org.). O Brasil: território e sociedade no início do século XXI. 5. ed. Rio de Janeiro; São Paulo: Record, 2003. 
SILVA, D. B. L. O Impacto da Abertura Comercial sobre a Produtividade da Indústria Brasileira. Rio de Janeiro: FGV, 2004.

SOJA, E, W. Geografias pós-modernas: a reafirmação do espaço na teoria social crítica. Rio de Janeiro, Jorge Zahar, 1993.

UNO/ECLAC. Strengthening development. The interplay of macro-and microeconomics. Santiago, Chile: ECLAC, 1996.

VESENTINI, J. W. A geografia crítica no Brasil: uma interpretação depoente. Departamento de geografia - FFLCH-USP, out. 2001. Disponível em <http://www.geocritica.hpg.ig.com.br/geocritica04-6.htm> Acesso em: 29 jun. 2006.

(Recebido em 20.02.2014. Aceito em: 14.06.2014) 